\title{
Experience of Implementing the Model of Innovation and Consulting Services for Agribusiness Entities in Russia
}

\author{
Elena Panina $^{1^{*}}$, Olga Frolova $^{1}$, Anatoliy Shamin ${ }^{1}$ and Alvaro Rocha ${ }^{2}$ \\ ${ }^{1}$ Nizhny Novgorod State Engineering and Economic University, Knyaginino, Russia \\ ${ }^{2}$ University of Lisbon - ISEG, Lisbon, Portugal
}

\begin{abstract}
The article is devoted to the assessment of existing level of development of information and consulting system in agricultural and industrial complex. The relevance of covering methodological issues is due to the current level of development of information and consulting services in regions, the rapid and large-scale expansion of the Internet space, the established world experience in introducing innovations, and the need to implement state policy in the field of agriculture. The paper considers the works of Russian scientists and economists on improving the system of agricultural consulting. The positive world experience of spreading an effective system of innovative and consulting services of rural areas is studied. For discussion, the authors propose a methodology for choosing a model of an innovative service center in rural areas. The effectiveness of application of comprehensive information system with the involvement of educational organizations is justified. The experience of functioning of Center for Support of Rural Development on the basis of regional university is presented. The authors formulate proposals for improving the innovation and consulting infrastructure in the agricultural and industrial complex in order to increase the efficiency of providing information and consulting services, increase the level of knowledge of rural population, the personnel of agricultural producers, disseminate information about the achievements of scientific and technical community, innovative developments and methods of management, effective interaction of agricultural entities, authorities, scientific and educational organizations.
\end{abstract}

The problems of implementing agricultural policy in the field of food security and regional independence, the need to accelerate the pace of import substitution, increase the competitiveness of products in the domestic and foreign markets of Russia, as well as solving the issues of rapid decline in the standard of living of the rural population, increasing the gap between the incomes of rural and urban farms, reducing the share of the total area of comfortable residential premises in rural settlements require attention of economists and the assistance of the state regulator.

Despite the measures taken by the state for the sustainable development of rural areas [1, p. 77], Rosstat experts note an increase in the urban population and a decrease in the

\footnotetext{
*Corresponding author: helenpanina@yandex.ru
} 
number of rural residents. So, in 2019, there were 94.9 thousand more urban residents compared to 2018. In 2019, the rural population decreased by 130.5 thousand people. Among the acute problems of rural areas, it is necessary to highlight the problems of rural unemployment and the lack of developed social and telecommunications infrastructure [2], problems directly related to the use of agricultural land, regardless of ownership [3, p.83].

The implementation of the program for sustainable rural development 2020-2025 determines the achievement of a permanent improvement in life support, living conditions of people and the transition to qualitatively new standard of living in the era of the digital economy, in which the ecosystem is not destroyed and the natural basis is preserved.

On the other hand, promoting the competitiveness of Russian agricultural products and improving the quality of life in rural areas is largely achieved through the introduction of innovations, digitalization, and the dissemination of relevant information among agricultural producers and rural population.

One of the key directions of modern state policy is the development of information and consulting services at regional level. The main task of the service is the social and economic modernization of modern agricultural sector with the help of consulting tool and the transition to an innovative aspect of activity. Agricultural consulting provides solutions to the following tasks:

- broadcasting information about innovative developments, new management methods, achievements of scientific and technological progress, improving skills in the application of agricultural technologies;

- increasing the level of knowledge of rural population in various areas in agricultural sector, assistance in mastering innovative and progressive experience of agricultural and industrial production;

- providing consulting assistance on the entire range of issues related to the financial and economic activities of agricultural producers;

- implementation of training and retraining of the personnel of commodity producers, professional development and formation of the personnel reserve of agricultural consulting subjects;

- improving the development of international cooperation, interaction with government authorities, scientific and educational organizations and agribusiness entities.

The choice of the innovation center model is considered by the authors to be one of the fundamental methodological aspects in the implementation of tasks of promoting the dissemination of information necessary for agricultural producers and the rural population at the regional level.

The works of Russian scientists such as G. M. Demishkevich [4], I. S. Sandu [5], M. Ya. Veselovsky [6], Yu. I. Klimenko [7], V. V. Lazovsky [8] and others are devoted to the issues of formation, development of information and consulting services, and improving the efficiency of information and consulting services provided.

The works of Z. M. Alborova [9], S. A. Belykh [10], Yu. V. Goryushina [11], A. A. Poddubny [12], E. V. Kopylova [13] cover the issues of effective development of information and consulting services.

The experience of choosing a model for the functioning of information and consulting center is covered by academic economists in scientific works from various aspects. At the same time, the issues of improving the system of agricultural consulting (its effective reproduction) remain debatable and require coverage and scientific justification.

The international experience of functioning of innovative centers of agricultural consulting on the basis of departments and ministries of agriculture, at universities and agricultural colleges, as part of associations of commodity producers or commercial structures proves its effectiveness. Consulting services as a form of knowledge 
dissemination among agricultural producers and the rural population have been working for decades.

In Russian practice, the "ministerial" model of the innovation center's activity at the regional level often prevails. The model has absolute advantages in terms of the ability to influence the formation of state policy in agricultural and social sectors of the region's economy. Specialists of the service take part in the development of regional programs in the agricultural sphere. The model allows strengthening influence in the regions, managing individual processes of innovative development of the economy. At the initial stage, the administrative resource allows to achieve the planned indicators as quickly as possible if there are qualified personnel and a material and technical basis.

There is a Russian experience of spreading the "university" model of ICS. When organizing the information and consulting service, a powerful material and technical and educational-methodological base of universities, the experience of scientific and pedagogical personnel, and the equipment of laboratories of various profiles are used. Universities guarantee high-quality consulting services to commodity producers almost in all areas of agricultural science and practice. The presence of authority in the regions allows universities to have a significant influence on the formation of agricultural policy. Agricultural producers trust teachers, openly turn to the service for advice. Dynamic development of the personnel potential of the center's consultants is ensured.

The authors consider it expedient to propose the distribution of the combined model of the innovation center based on the existing foreign and Russian experience and to implement at the regional level an organizational structure that could combine the systems of personnel training, consulting and act as a link in the "chain" state-educationbusiness/farmers-population.

Foreign experience of such a "cooperative" model is widespread in the United States, Poland, Israel and many other countries. The work of the centers is carried out on the basis of partnership with educational institutions and experimental stations. Universities develop specific programs that are implemented at the local level in the districts [4]. The teaching staff of educational institutions interacts with private investors on the basis of individual contracts and conducts research and experiments.

For example, in the United States, in each state, a federal law assigns a leading university the obligation to provide information services to the public in the field of competence. The "extension-service-center service" is organized by faculty type within the university hierarchy. It cooperates exclusively with the local population.

The service in University Purdue University Cooperative Extension Service (USA, Indiana) is engaged in educational and scientific activities in the field of agriculture, crop production, veterinary medicine and agricultural economics. The center is a network of colleges, branches of the university, in close cooperation with the American Department of Agriculture. [14]

Israel's experience in agricultural achievements, taking into account the unfavorable geographical characteristics of the country's location and natural factors, is advanced on a global scale. As a result of thoughtful investments, Israel has a highly developed agriculture. The use of advanced developments in agriculture based on the research of Israeli universities allows having high economic indicators and occupying a leading world position.

At Israel's universities, funds to support new developments (technology transfer companies) are organized. Mutual cooperation of agricultural producers directly with teachers of educational organizations is widespread.

Financing of project and innovation activities is carried out on the principles of publicprivate partnership. For example, at the Ariel University in Samaria, annual programs are 
distributed with $10 \%$ of the contribution of the enterprise interested in the project, and $90 \%$ of the funds come from the fund or the state program.

The Scottish Agricultural College is one of the basic centers of information and consulting services for the rural population and agricultural producers in the UK. The financing of the service's activities until the 90 s of the XX century was carried out at the expense of the budget and information was provided to farmers free of charge. But the UK government has demanded the adoption of a "customer pays" reimbursement system for certain categories of services in the areas of social security, pollution control and farm diversification. Other services have become paid for users. This approach made it possible to expand the service area of the center to the entire territory of the UK, to attract large agricultural producers for consulting services [15].

Some scientists note the positive impact of the "university" model in the modern Russian practice of forming an agrocluster [16, p. 69]. The impact is most obvious at the initial stage of clustering formation due to the high scientific potential. A successful example of the functioning of the innovation center of the "cooperative" model in the field of horticulture is the information and consulting support of Michurin State Agrarian University and All-Russian Research Institute of Horticulture named after I. V. Michurin $[17$, p. 40].

Since mid-1996, the Russian Innovation Center for the study of the heritage of the village has been successfully operating with the involvement of the teaching staff, students and postgraduates of Russian State Agrarian University-Moscow Agricultural Academy after K. A. Timiryazev. The Center develops innovative programs to replicate the results of applied scientific research in rural areas.

The approach of close cooperation of agribusiness with universities in information and consulting services in agriculture shows its effectiveness in world practice.

Based on the systematization of Russian and foreign practice, the authors propose a model of an innovation and consulting center (Fig. 1). The model combines the "university" and "ministerial" options. The center's activities are financed from the budget. Among the advantages of the model, it is necessary to highlight the increase in the level of knowledge of the rural population, professional development and formation of the personnel reserve of agricultural consulting subjects, training and retraining of the personnel of commodity producers, consolidation and broadcasting of information about innovative developments, new management methods, achievements of scientific and technological progress, improving the skills of applying agricultural technologies; ensuring the accelerated implementation of the results of scientific research in agriculture. 


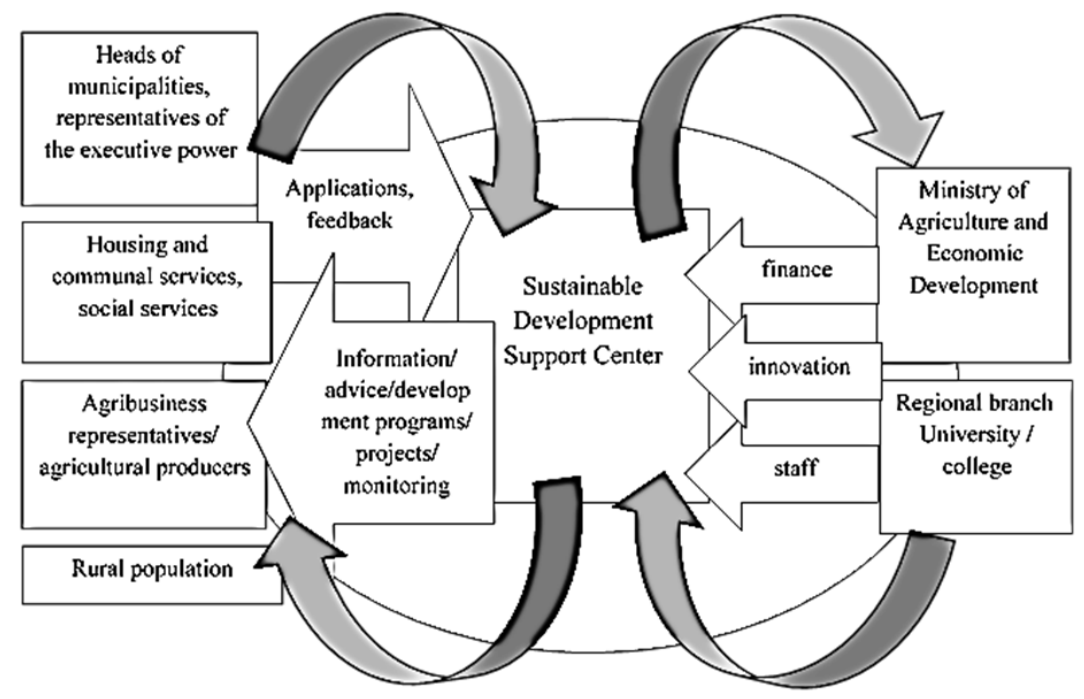

Fig. 1. Model of the center of innovation and digital type of educational and consulting activities

The model meets the requirements of the innovation and digital aspect, allows to perform not only academic, educational or integration, consulting functions separately, combines the potential depending on the goals of the center and social and economic development of the area, develops human resources in the agricultural and industrial complex, helps to reduce rural unemployment. This model of ICS sets an innovative vector of development, ensures the interaction of government authorities, agricultural producers, the scientific community and civil society.

As an example of implementation of proposed model in Nizhny Novgorod Region, a regional center for support of sustainable rural development was established at the regional university - Nizhny Novgorod State Engineering and Economic University. The Center coordinates the implementation of regional sustainable development program. The teaching staff of University takes an active part in the work of this Center. Ministers, deputies, representatives of municipalities in the region and other responsible persons interested in a stable improvement in the quality of life in rural areas attend meeting in this Center.

The peculiarity of this center is that it is created on the basis of university in one of the municipal districts of the region, where there are 2,000 students per 8000 inhabitants. The scientific and pedagogical staff and students mostly live in rural areas of the region. The problems of rural development are known to many from personal experience.

The Center provides scientific and practical support of transformation processes for individual districts and municipalities of Nizhny Novgorod region. Scientific research on the economic development of rural areas is conducted by the teaching staff of University. The specialists of the center conduct systematic work on the methodology of development programs, study successful development experience, analyze development prospects, study problematic issues, and negative factors. Proposals are resonated at the level of representatives of the executive branch and are practically implemented.

The Center acts as a coordinator between government authorities, scientific and educational organizations, agribusiness entities, and the rural population. Visiting sessions are organized with presentations of programs of settlement development strategies and practical proposals are formulated for the implementation of programs for the development 
of municipalities in Nizhny Novgorod region. Local residents take an active part in the discussion of territorial development programs.

The presence of stable material and technical base of university with an agricultural profile allows Center to use and consolidate information about innovative developments, apply innovations of agricultural and industrial complex in scientific and practical activities. In addition, in our opinion, the work of Center allows to carry out an information and consulting function at the regional level and provide relevant information to rural population in various areas of activity in agricultural sector. Consulting work can be carried out both among the rural population in the field of informing residents of remote territories of the region about the ways of doing business in the agricultural sector, agricultural cooperation, and also among small and medium-sized businesses on issues of interest.

Thus, when choosing the ICC model, it is necessary to pay attention not only to the choice of organizational and legal form of center, cost-effectiveness of the model, availability of up-to-date arrays of information bases, effective ways of organizing and managing the agricultural consulting system. An important factor in the implementation of ICC model is defining the category of users with center information, availability of feedback on requests and monitoring of requests/needs for information. At present stage of ICS development, intellectual capital, transformation of human resources is of paramount importance, because it provides an increase in social and economic effect, forms and improves the mechanisms for improving the efficiency of consulting infrastructure at mesolevel [18]. The formation of innovative network centers at the regional level allows solving effectively the problems of closed loops and vertical interaction systems. It is characterized by flexibility and immediate transformation to changes in market requirements.

\section{References}

1. Shamin A. E., Provalenova N. V. Organizational and economic conditions for the development of social infrastructure in rural areas// Bulletin NGIEI, No. 1 (104) (2020).

2. Proskura N. V. An approach to systematization of rural territories for choosing the direction of development of telecommunications services. / / in the collection: Actual directions of fundamental and applied research. Proceedings of XXIV International Scientific and Practical Conference. Morrisville (2020).

3. Surova T. S., Mishina Z. A. Changing forms of land ownership as a tool for stimulating the development of agriculture // Bulletin NGIEI, No. 3 (106) (2020).

4. Demishkevich G. M. Formation and development of agricultural consulting system: abstract of the dissertation of the Doctor of Economic Sciences. Yekaterinburg (2009).

5. Theoretical and methodological aspects of the formation of the Institute of agricultural consulting /ed. by I. S. Sandu, G. M. Demishkevich/ - M.: VNIIESH (2012).

6. Veselovsky M. Ya. Information and consulting service of the agroindustrial Complex of Russia (Questions of theory and practice) [Text] / M. Ya. Veselovsky. - Moscow: Rosinformagrotech (2002).

7. Klimenko Yu. I. Tasks of the system of agricultural consulting on innovative development of production / / APRIORI. Series: Natural and Technical Sciences. No. 1 (2014).

8. Lazovsky V. V., Bautin V. M. Agricultural consulting in Russia in the twentieth century: From social agronomy to ICS of agricultural and industrial complex - Moscow: Kolos (1999).

9. Alborova Z. M. Models of organization of information and consulting services on the basis of established agricultural structures: on the example of the Republic of North 
Ossetia-Alania: abstract of the dissertation of the Candidate of Economic Sciences: 08.00.05 / Alborova Zarina Muratovna; [Place of defense: All-Russian Institute of Agrarian Problems and Informatics named after A. A. Nikonov]. - Moscow (2013).

10. Belykh S. A. Management of economic potential of small forms of farming in agricultural production: on the materials of Perm region: abstract of the dissertation of the Candidate of Economic Sciences: 08.00.05 / Belykh Svetlana Aleksandrovna; [Place of defense: Ural State Agricultural Academy.].- Yekaterinburg (2011).

11. Goryushina Yu. V. Information and consulting support for activities of agricultural producers: on the materials of Tambov region: abstract of the dissertation of the Candidate of Economic Sciences: 08.00.05 / Goryushina Yuliana Vadimovna; [Place of defense: Place of protection: All-Russian Institute of Agrarian Problems and Informatics named after A. A. Nikonov]. - Moscow (2013).

12. Poddubny, A. A. Information tools for the development of agricultural and industrial complex of the region: abstract of the dissertation of the Candidate of Economic Sciences: 08.00.05 / Poddubny Alexander Alexandrovich; [Place of defense: Adyghe State University]. - Maykop (2011).

13. Kopylova, E. V. Development of information and consulting support for agricultural consumer cooperatives: abstract of the dissertation of the Candidate of Economic Sciences: 08.00.05 / Kopylova Elena Vasilyevna; [Place of defense: Nizhny Novgorod State Engineering and Economic Institute]. - Knyaginino (2014).

14. Ksenofontova O. L. American experience of University Purdue University Cooperative Extension service in providing consulting and educational services to population // Modern high-tech technologies. Regional application. No. 1 (2007).

15. N.H.C. Sparks. User Fees for Land Grant Universities-the Scottish Experience. Poultry Science, 78 (1999).

16. Kaleev N. V., Kuchin N. N. Cluster technologies as a tool for improving the work of the dairy subcomplex of the region // Bulletin NGIEI. 2020. No. 6 (109).

17. Grebenshchikov I. Cluster initiatives in the field of agricultural education and science. No. 8 (2012).

18. Panina E. V. Methodic and methodological foundations of the formation of consulting infrastructure in the economy of the region. Monograph // Mordovchenko N. V., Panina E. V. -N. Novgorod (2018). 